\title{
悪性グリオーマに対する抗癌剤局所投与療法
}

\author{
Neocarzinostatin の腫瘍腔内投与療法 \\ 植村正三郎・松角 康彦・倉津 純一・園田寛·大塚 忠弘·吉岡 進 \\ 山田 正彦
}

\section{Local Chemotherapy of Malignant Glioma}

Intra-tumoral Administration of Neocarzinostatin

\author{
Shozaburo Uemura, Yasuhiko Matsukado, Jun-ichi Kuratsu, Hiroshi SonOdA, \\ Tadahiro OHtsuka, Susumu Yoshioka and Masahiko Yamada \\ Department of Neurosurgery, Kumamoto University, Kumamoto
}

\begin{abstract}
The authors present the results of intra-tumoral chemotherapy as a maintenance therapy for malignant glioma after remission induction therapy. The treatment was repetitive local administration of neocarzinostatin (NCS) into the tumor cavity through Ommaya's reservoir. Five of 6 treated cases survived over 1 year, and the other case expired 10 months after the therapy due to brain stem dissemination of the glioma, although the primary tumor was reduced in size on computed tomography (CT). Three out of 5 patients who survived over 1 year expired within 2 years, due to regrowth of the residual tumor in 2 cases and pneumonia in the third. One case has lived over 4 years. The good candidate for the intra-tumoral local chemotherapy was a patient with a singlecavity tumor and little residual tumor on CT. Histological examination using fluorescence micrograph showed that the fluorescein-labeled NCS had diffused into the tumor through the wall of the tumor cavity over $5 \mathrm{~mm}$. Vacuolar degeneration and necrosis of the tumor cells and hyalinoid degeneration of the tumor vessels were the most characteristic findings. Side effects such as convulsion, hemiparesis or progression of cerebral edema on CT were not noted, but intra-tumoral hemorrhage was seen in one patient, who received about $100 \mu \mathrm{g}$ NCS in one shot. Cytological examination of the liquid content of the tumor cavity during the treatment showed abundant macrophages with destroyed tumor cells. NCS was found to be the more effective drug not only as an anti-cancer agent, but also as an immunotherapeutic agent.
\end{abstract}

Key words: malignant glioma, neocarzinostatin, intra-tumoral chemotherapy, macrophage

\section{Iはじめに}

最近，覀性腫瘍の治療成績が徐々に向上しつつあるなか で，恶性グリオーマの場合には種々の治療法の導入や抗癌 剂の開発にもかかわらず，その治㞠成績はい专だ悲観的と
吾わざる在得ない，従来より我々は，各種抗癌剤のなかで も特に悪性グリオーマに対する蛋白性抗癌抗生物質である neocarzinostatin(NCS)による治療を，内頸動脈動注や粫道 腔内投与と放射線併用憭法により試みてきた151が，今回は 宽解導入療法後の維持療法の一部として, 残遺腫煌腔に 
Ommaya's reservoir を設置してNCS $\sigma$ 局所投与療法を施 行し，その治撩成績と治㞠効果に影響を及ぼす因子につい て㛟討した。

\section{III対象および方法}

\section{1. 対象}

腫瘍腔内抗癌剂投与療法(intra-tumoral chemotherapy) を施行した症例任 6 例で，年齢は 9 65才，男性 4 例，女 性 2 例で，いずれも悪性グリオーマと診断され，手術，放 射線療法，化学療法を終了したのちの症例である(Table 1).その5ち〈症例 4，5〉を除く4例はいずれも再発腫痬に 対して治療が施行されたものであり，特に〈症例 2,3,6〉 は初回手術時の手術所見および病理組織学的所見より良性 の星細胞腫と診断され，それぞれ 3 年から 5 年の間経過観 察が行われていたが，再発時の脳血管撮影，CT，手術所 見㧍上び病理組織学的所見上り悪性星細胞腫( malignant astrocytoma）上診断されたもので，いわ切る星細胞腫の悪 性変化 (malignant change)例であった。な押，1例老除き 今回の治療前にそれぞれ 1 3 回の開頭術と1〜2回の放射 線萘法 (総線量60〜108 Gy) を，3〜5 年の間に受けていた。 〈症例 1，3，4，6〉に扮いては乎術時に腫瘍摘出腔内に
Ommaya's reservoir を設置し，〈症例 2, 5〉では CT で霬胞 珄にみえる腫瘍に対して biopsy を行い同時に Ommaya's reservoir 設置した。

\section{2. 治療方法および効果判定}

抗癌䬉としてNCS を用いたが，それぞれの Ommaya's reservoir 経皮的に穿刺し，まず腫瘍腔内を $10 \sim 20 \mathrm{ml}$ の 生理食塩水にて洗濑したのち，NCS $20 \sim 100 \mu \mathrm{g}$ を含む牛 理食塩水 $1 \sim 2 \mathrm{~m} l$ を 1 2 回/週の間隔で反復投与した。治 療期間は腫瘍腑内容液の細胞診とCT 所見を参考にしつ つ，維持㞠法として可能な限り継続した。治潦効果は，神 経症状, Karnofsky performance status (KPS $)^{3)}$, CT 検查な どにつき定期的に経過観察し判定した。

\section{III 結 果}

\section{1. 腫場組織内への NCS 移行}

開頭術下，硬膜切開後脳表より腫瘍腔内を穿刺し， fluorescein labeled NCS (FITC-NCS) $50 \mu \mathrm{g} / \mathrm{ml}$ を one shot 法で投与した。 5〜10分後に震胞壁を含九だ腄場を摘出し， 迅速凍結切片を作製して巣光顕微鏡で険索したところ， FITC-NCS が腫瘍壁より $5 \mathrm{~mm}$ 以上の深さまで到達して いることが確認された(Fig. 1)

Table 1 Results of intra-tumoral neocarzinostatin (NCS) administration therapy

\begin{tabular}{|c|c|c|c|c|c|c|}
\hline $\begin{array}{l}\text { Case } \\
\text { No. }\end{array}$ & $\begin{array}{l}\text { Age, } \\
\text { Sex }\end{array}$ & $\begin{array}{l}\text { Location and } \\
\text { histology }\end{array}$ & Previous treatment & $\begin{array}{l}\text { Total doses of } \\
\text { intra-tumoral } \\
\text { NCS }(\mu \mathrm{g})\end{array}$ & $\begin{array}{l}\text { Tumor } \\
\text { regrowth on } \\
\text { follow-up CT }\end{array}$ & $\begin{array}{c}\text { Results } \\
\text { (Interval }\end{array}$ \\
\hline 1 & $9, \mathbf{M}$ & $\begin{array}{l}\text { lt. temporal } \\
\text { glioblastoma }\end{array}$ & 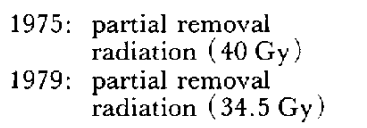 & 100 & - & $\begin{array}{l}\text { KPS } 90 \% \\
\rightarrow \text { KPS } 90 \% \\
(3 \text { years })\end{array}$ \\
\hline 2 & $26, \mathrm{M}$ & $\begin{array}{l}\text { lt. fronto- } \\
\text { temporal } \\
\text { malignant } \\
\text { astracytoma }\end{array}$ & $\begin{aligned} & \text { 1978: } \text { biopsy } \\
& \text { radiation }(50 \mathrm{~Gy}) \\
& \text { 1981: } \\
& \text { biopsy } \\
& \text { radiation }(58 \mathrm{~Gy})\end{aligned}$ & 640 & - & $\begin{array}{l}\text { KPS } 90 \% \\
\rightarrow \text { KPS } 90 \% \\
\text { (9 months) } \\
\text { rapid death; } \\
\text { CSF meta. } \\
\text { (10 months) }\end{array}$ \\
\hline $3^{* *}$ & $28, F$ & $\begin{array}{l}\text { bifrontal } \\
\text { malignant } \\
\text { astrocytoma }\end{array}$ & $\begin{aligned} \text { 1976: } & \text { biopsy } \\
& \text { radiation }(50 \mathrm{~Gy}) \\
1981: & \text { partial removal } \\
& \text { radiation }(34.5 \mathrm{~Gy}) \\
& \text { carotid NCS }(2.5 \mathrm{mg})\end{aligned}$ & 100 & + & $\begin{array}{l}\text { KPS } 60 \% \\
\rightarrow \text { KPS } 40 \% \\
(1 \text { year })\end{array}$ \\
\hline $4^{* *}$ & $65, \mathrm{M}$ & $\begin{array}{l}\text { rt. parietal } \\
\text { glioblastoma }\end{array}$ & 1981: $\begin{aligned} \text { partial removal } \\
\text { radiation }(60 \mathrm{~Gy}) \\
\text { carotid NCS }(2.5 \mathrm{mg})\end{aligned}$ & 100 & - & $\begin{array}{l}\text { KPS } 60 \% \\
\rightarrow \text { KPS } 60 \% \\
(1 \text { year })\end{array}$ \\
\hline 5 & $30, \mathbf{M}$ & $\begin{array}{l}\text { rt. thalamus } \\
\text { malignant } \\
\text { glioma }\end{array}$ & 1982: $\begin{aligned} & \text { shunt, biopsy } \\
& \text { radiation }(60 \mathrm{~Gy})\end{aligned}$ & 650 & + & $\begin{array}{l}\text { KPS } 80 \% \\
\rightarrow \text { KPS } 20 \% \\
(1 \text { year })\end{array}$ \\
\hline 6 & $32, \mathrm{~F}$ & $\begin{array}{l}\text { rt. temporal } \\
\text { malignant } \\
\text { astrocytoma }\end{array}$ & 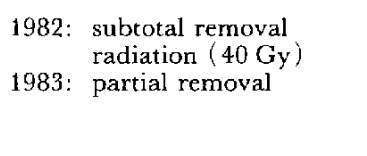 & 1,430 & + & $\begin{array}{l}\text { KPS } 40 \% \\
\rightarrow \text { KPS } 40 \% \\
(1.5 \text { years }) \\
\text { [tumor } \\
\text { bleeding] }\end{array}$ \\
\hline
\end{tabular}

*Interval between before and after intra-cavitary NCS administration. ** Included in the previous report. ${ }^{15)}$ CT indicates computed tomography; KPS, Karnofsky performance status ${ }^{3 !}$; meta., metastasis; carotid NCS, intra-carotid NCS perfusion. 


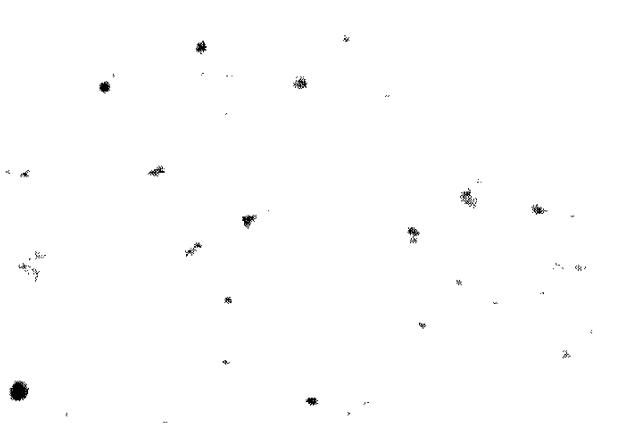

Fig. 1 Diffusion of fluorescein-labeled neocarzinostatin (FITC NCS ). Five minutes after $50 \mu \mathrm{g}$ FITC-NCS injection in the cystic cavity of the tumor (Case 6 ). $\times 100$

\section{2. 治療成績}

腫瘍腔内抗癌剂投与憭法の治療成績は Table 1 亿要約し た。 NCS 総投与量法 $100 \sim 1,430 \mu \mathrm{g}$ ，投与回数も5〜18 [回] まで上掟例に上ってばらつきがあった。6例のうちく拝例

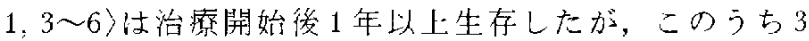
例は 2 年以内に死亡した。特に〈症例 1$\rangle$ は，すでに治撩㣪 4 年以上経過して再々発はみられず，CT上でも腫瘍の襄 胞性の部分は檄小倾们がみられた(Fig. 2)。〈症例 3,5〉は

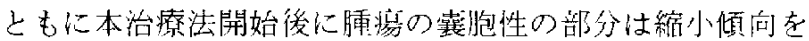
示したが，残遗実澌性蝩瘍の浸潤に上り死亡した。〈将例 2〉は biopsy 後のわずかな腫愓腔に Ommaya's reservoir が 設置されたが，本治療洁開始後は残遺先質性腫痬も縯小し つつあり，9 カ月後の KPS は90\%であった。しかし，10 力月目に下部脳神経疜状が急速に進行し, 腫㟫の脳幹部沶 よび上位頸解付近への転移がCT 上でも捉えられ，开入院 缓わずか 1 週間で死亡した(Fig. 3)。〈证例 4〉は部分切除， 放射線憭法などの治療後も，CT上造影剤にてリング状に 增强される部分が笺存していた。本例の腫揚腔内 NCS 投 与療法開始時の KPS は60\%であったが，1年後も腫愓は 残存(当初よりやや縮小)しながらも KPS は $60 \%$ の状態を 保っていた，本例はその後も再增殖の傾向老示さなからた が，1 年 5 力月目に急性肺炎で死しした(Fig. 4)。(证例

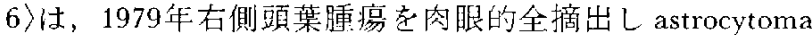
grade 20 芮理診断であった。1983年，睡瘍再々発に対し て部分邚除上外減压を施行し，最終的に malignant astrocytomaの診断がなされ，腫揘摘出脂内に総呈 $1,4.30$ $\mu \mathrm{g} の \mathrm{NCS}$ が反復投与された。本例は, 腄瘍摘出腔内一の NCS 総投与量が $700 \mu \mathrm{g}$ 上なる项より Ommaya's reservoir 加ら採取する腫瘍摘出腔内液が徐々に血性となり，止克進 症状も出現した。CT 所見扔よび再々手術の結果，腄湯摘
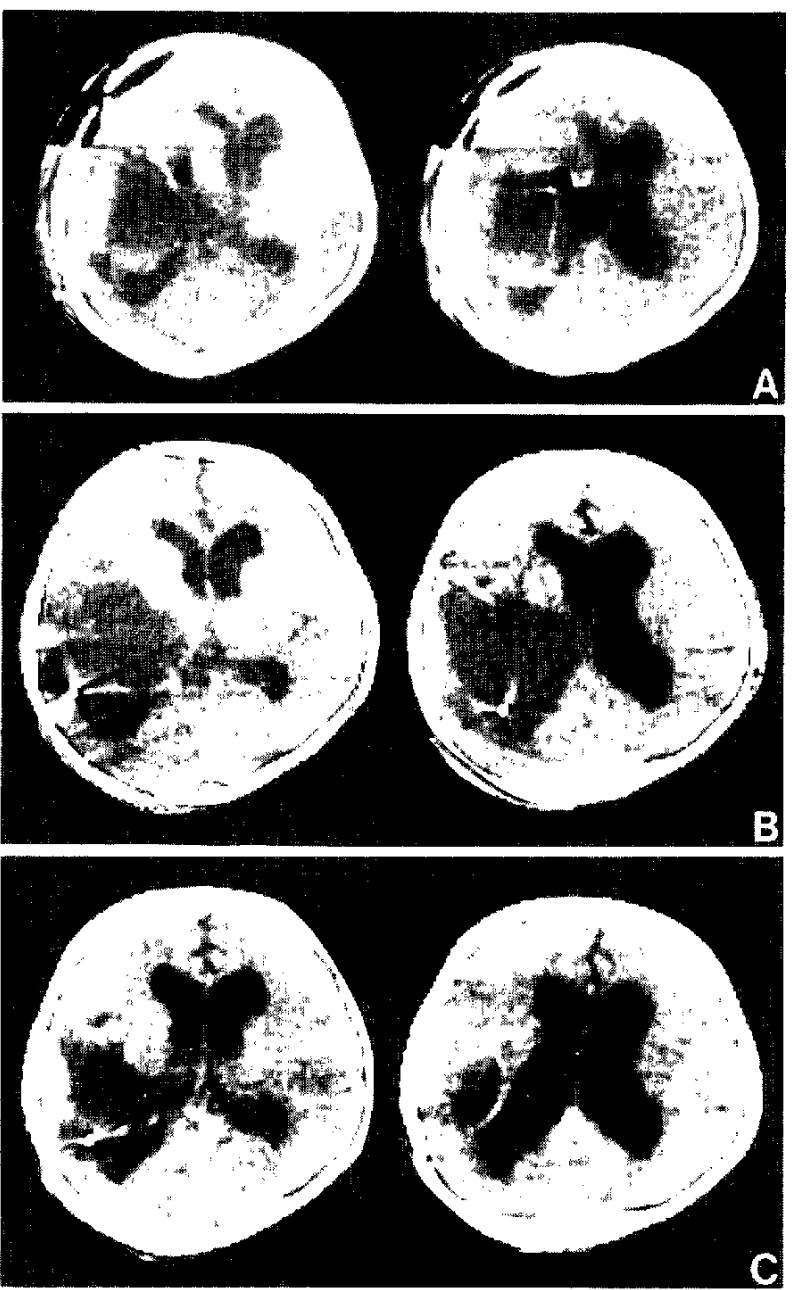

Fig. 2 Sequential computed tomography (CT) scans in Gase 1, glioblastoma. A: Plain C'I' after extensive resection of the tumor (September 1979). B: Plain CT after irradiation $(34.5 \mathrm{~Gy})$ and intra-cavitary $\operatorname{NCS}(100 \mu \mathrm{g})$ (May 1980). C: Plain CT 2 years after the therapy (September 1982). No evidence of progressive tumor growth can be seen

出腔内に血腫が存在しこの内側の寒質性組織の部分も摘出 したところ，組織学的に腫場細胞の空胞変性・壊死，血管 の硝子様変性，およびgliosisがみら扎た(Fig. 5).

1 年以上生存した 5 例について，本治燎開始後任ぼ 1 年 月のCT所見を治療開始前のCT上此較した。1 年目の CT 上で腫場の增大がみられなかった例(〈症例 1，4〉)の治 療前 CT 所見は，(1)䏦瘍腔が single cavityである，(2)造影 剂投与後のリング状腫将壁が薄いことが特徵的で，一方 1 年日 CT で䏦場の增大がみられた症例(症例 3，5〉)の治療 前 CT 所見は，(1)腫瘍腔が多胞性である，(2)线遺腫瘍が大 きく浸潤の範曲が広いなどが特徵として举げられた。また 

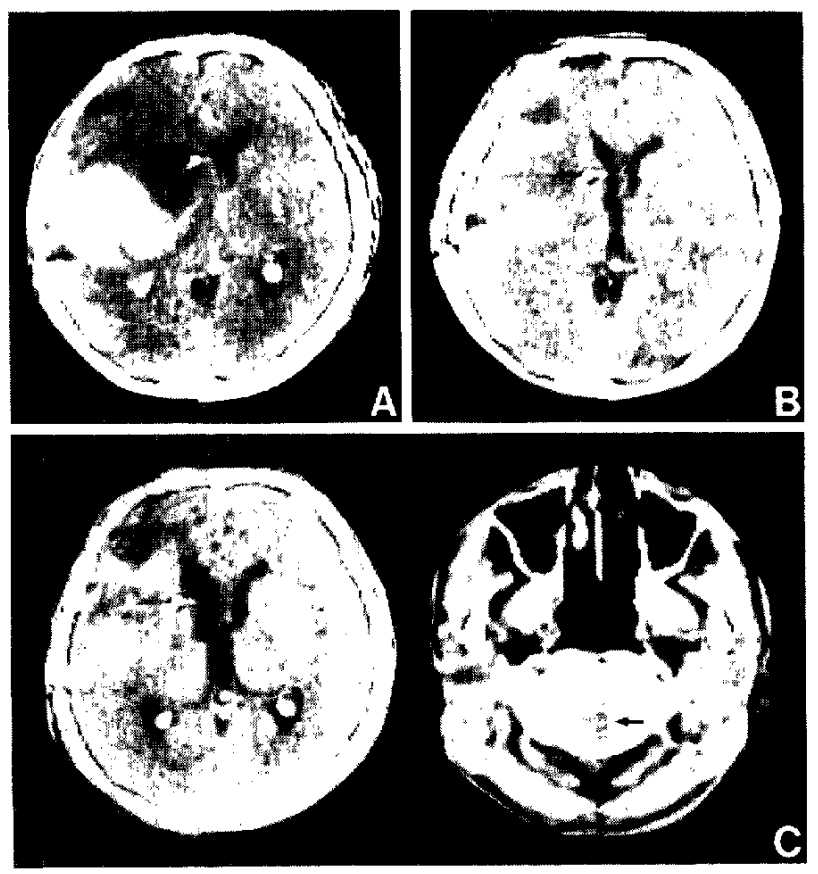

Fig. 3 Sequential CT scans in Case 2, malignant astrocytoma. A: After the tumor biopsy. Setting of Ommaya's reservoir, external decompression and whole head irradiacion $(50 \mathrm{~Gy})$ was performed. The tumor is increased in size. Intra-tumoral NCS therapy was started (total: $640 \mu \mathrm{g}$ ). B: Six months after the intra-tumoral NCS therapy. The tumor is reduced leaving a partially enhanced lesion. C: Ten months after the treatment. The tumor is more diminished in size and left lateral ventricular dilatation is seen (left). Dissemination to the medullary portion (arrow) is seen (right); the patient expired.

(怔例 2)では，治療後10力月月のCTで原発巣の腫瘍は縮 小していたが，脳幹部一の転移が認められた。

\section{3. 腫瘍腔内細胞の変化}

本治療法施行中，静止スメア法にて穿刺滠の細胞につい て検索した。多くの症例では，治潦開始当初は変性した畩 死組織あるいは腫境細胞がみられ，特にく症例 1, 5〉では腫 瘍細胞に混じって貪食現象(phagocytosis)を示す細胞が出 現し，これは non-specific esterase 染色法によりマクロフ アージであることが判明した(Fig. 6)。このマクロファー ジの增加は，治療を継続して腫瘍細胞が消头あるいは著明 に減少するに従って少なくなっていく傾问があった。

\section{4. 副作用}

一般的に抗癌剤療法にみられるような副作用は全例上も にみられなかった。しかし，1回投与量が通常(20〜50 $\mu \mathrm{g})$ よも多かった〈症例 6$\rangle(100 \mu \mathrm{g})$ に腫瘍腔内出血がみ られた。
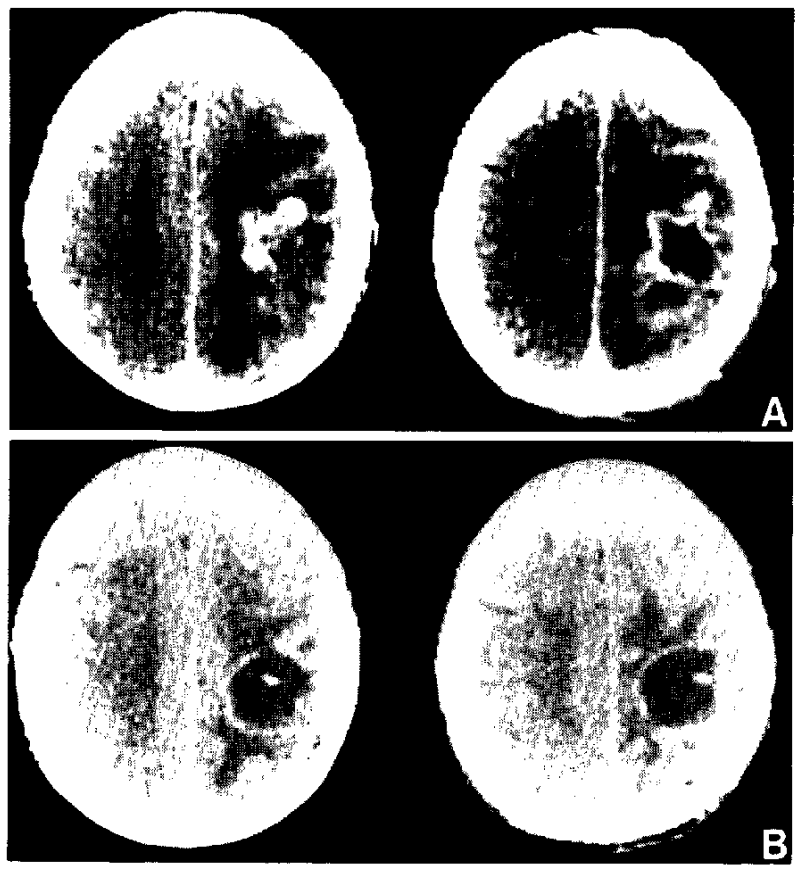

Fig. 4 Sequential CT scans in Case 4, glioblastoma. A: After partial removal of the tumor, irradiation $(60 \mathrm{~Gy})$ and intra-carotid NCS perfusion $(2.5 \mathrm{mg})$, an irregularly enhanced tumor and peripheral edema are recognized. B: One year after the therapy, ring enhancement and peripheral edema are still seen. But the enhancement has become thin, and the Karnofsky performance status $(60 \%)$ of the patient was not worsened.

\section{IV 考察}

\section{Intra-tumoral chemotherapy の背景と薬剤の選択}

脳腫瘍治撩法のなかで腫瘍摘出腔内あるいは囊胞性腫場 腔内に抗癌剂や放射性物質を直接投与寸るという試みは, 囊泡性䫓蓋咽頭腫に㧍けるブレオマイシン注入潦法や, ${ }^{198} \mathrm{Au}^{-}$コロイドによる内照射潦法沶どが知られている。 グリオーマについては, 1963年 Heppner ${ }^{1}$ が腫痬剔出腔内 に cytostatic agents 孝投与したという報告があり， Ringkjob ${ }^{9)}$ はグリオーマ手術時残遺喠瘍表伯に抗癌剂(5FU，Tio-Tepaなど)を浸したゲラチンスボンジを线して局 所㞠法を行い，剖検後の病理組織所見に执いて抗癌剂によ る脳および腫浆組織の変化はなかったと報告している。そ の後 Ommaya's reservoir 在利用した局所療法が行われる ようになり，竹内ら ${ }^{31}$ はブレオマイシンを用いて有効であ ったと報告し，Tator ${ }^{14}$ は奏駼脳腫瘍内に CCNUの局所注 入坴行ったところ毒性が少なく有効であったと報告してい る。また，点村ら101はアドリアマイシンによる反復局所注 


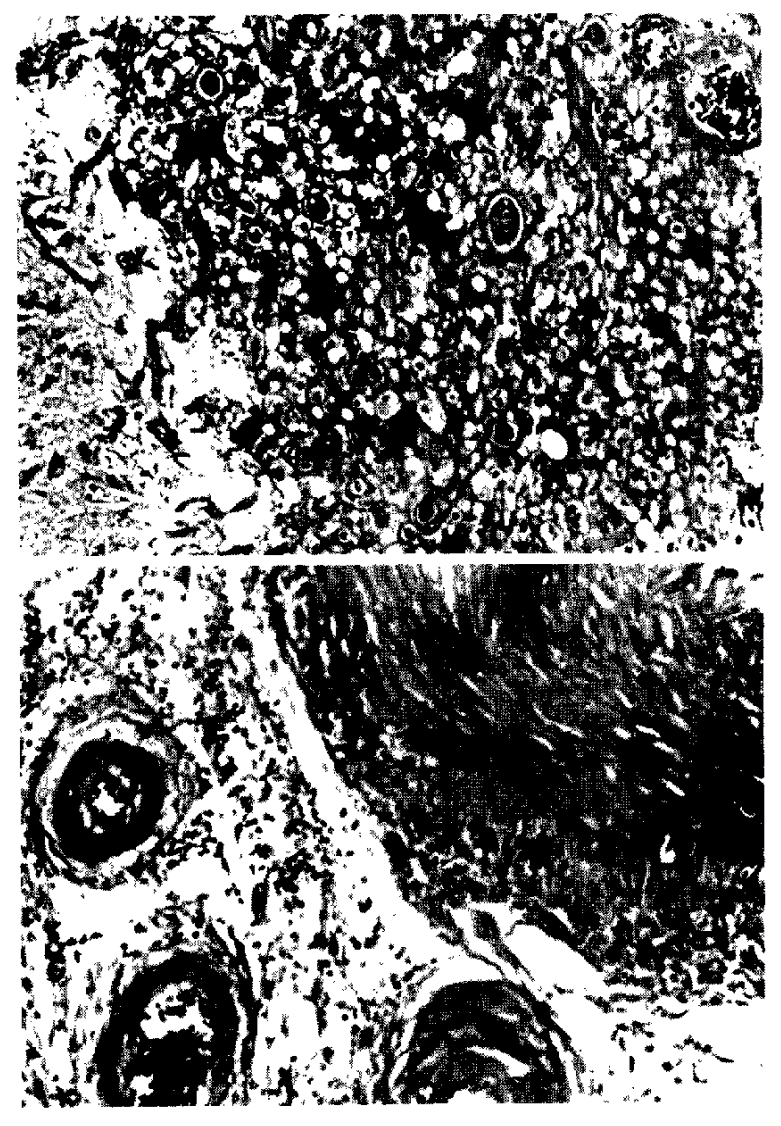

Fig. 5 Histological findings of Case 6 at the time of hematoma evacuation and partial removal of the tumor. Vacuolar degeneration and necrosis of the tumor cells and hyalinoid degeneration of the tumor vessels are recognized. HE stain, $\times 100$.

入㙩法を施行した15例の治㞠効果と組織所見を報告し，こ

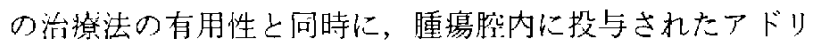
アマイシンが腫瘍組織内で長時間有効濃度を保っことを示 した。グリオーマの局所療法としては，最近になって ACNUやアドリアマイシンなどの抗癌戍，インターフェ ロンや溶連菌製剂を Ommaya's reservoir 通して腫韵空 内に投与寸る方法などが散見されつつあるが，いまだその 治療効果について評価できる段階に至っていない，

脳腫瘍の化学療法に際して，血行性に投与寸る埗合には 血液脳関門(BBB)を通りやすい脂溶性の薬剤，才なわち二

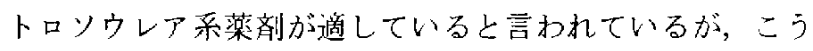
した薬剂はきわめて短時間に血管內に移行するため腫瘍脚 内に直接投与寸るには不適当であると考えられる，腫淘腔 内に投与された梁郕は腫瘍組織内をいわゆる diffusion に よって通過していくと言われ，むしろ分子量が大きく吸収 されにくい薬剂のほうがより適しているものと考えられ

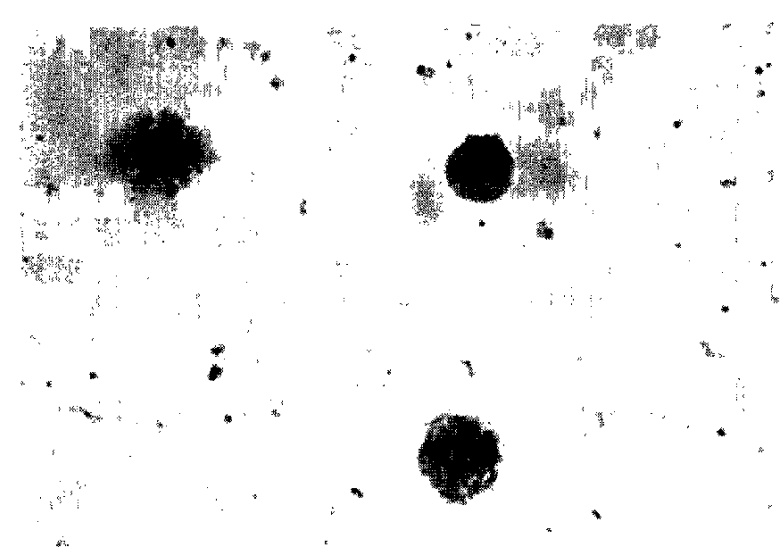

Fig. 6 Macrophages are recognized in the cystic tumor cavity of Case 1. Non-specific esterase staining, $\times 100$.

る。蛋白性抗癌抗生物質である NCS は, 不田 ${ }^{2}$ により放 線菌 streptomyces carzinostaticus varietas $\mathrm{F}-41$ の培盖濾液 より分離・精製された物質で，微量でも特にグリオーマに 対して選択毒性があり?，血中半減期12秒以下で娟液中で は16倍に延長する。この NCS の分子量は10,700と大きく， 腫瘍膑内投与㞠法に選抧すべき条件を満たした薬郕である 々判断した。 寸でに我々は，NCSを㵦液腔内に投与して

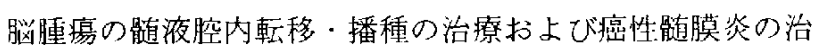
療に応用 (6)，その安全性・有効性について確認してお り，腫境腔内 NCS 投与量についてもこうした治憭経験を 参考として決定した。こうして腫瘍腔内に投与された NCS が，実際上腫瘍組織内に確実にdiffusionしている か，またその部での生物活性は䧽持されているかなどの問 題点については, 現段階でNCSの組織内濃度の定量法が ないため蛍光抗体法に上る定性法に上ってのみ検討され た.この結果, 腫瘍組織内では腫瘍腔壁より $5 \mathrm{~mm}$ の深さ までは十分に FITC-NCSが確認された(〈集例 3，6〉)。 NCS は生体内プロテアーゼにより不活性化されるがこれ は蛋白濃度の低い鹃液内に沙なく，このため随液内での NCSの半隇期が長くなると言われる。こうした事実より， 腫瘍腔内 NCS 療法を行う場合には腫痬腔内の蛋白濃度が 低いほうがより好ましいと考えられ，我々は生理食壏水に て十分洗湅したのちNCSの局所注入祭行った。

\section{2. 治療成綪}

埂瘍腔内 NCS 療法を行った症例の病態はそれぞれ異な って抢り, さらに放射線療法 (2 例は内頸動脈内 NCS 灌流 㙩法併用)後の維持療法であるため, 本治療法単独の有用 性についての結論はいまだ明確ではない。しかし，6例中 治療㣪 1 年以上を経過している 5 例が全例生存しており, 
さらにこの5例中 3 例が本治㞠法開始特のKPS 維持し ていること注本治療法の有用性を示していると考えられ る。治療後 1 年日の CT 所見上治療開始時の CT 比較し てみると，〈症例 1，2，4〉のごとく治燎開始時 CT で腫瘍 腔が single cavityで残遺腫瘍が小さい場合は 1 年徭のCT

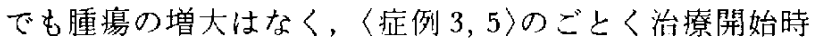
CT で腫瘍腔が多胞性で残遺腫煌が大きい場合には 1 年後 のCTで腫瘍はさらに増大していた。こうした事実より， 腫痬腔内抗漓剤療法を行5には手術時に可能な限り㕕範国 に腫瘍を剔出し，さらに腫場腔を single cavityと寸ること が必要となる。

武田ら ${ }^{12}$ 㴗性グリオーマに対して ACNUの局所投与 を行い，総量 $100 \mathrm{mg}$ 以上を投与した例で腫瘍腔内壁に沿 って10〜15 mm の壞死愿を認的たと報告し，さらにこう した治㞠中に腫瘍腔内壁に沿ってみられるCT上の enhancement 部が時に壊死巣を示すと述べている。我々の 〈症例 4〉では，1 年間にわたるCTの経過観察において終 始 enhancement の部分は变化して抢らず，組織学的確認 はなされていないものの壊死紧を示していた可能性は高い と考えられる。また(症例 6)では腫瘍腔内出血をきたした が，同時に摘出した血腫に面した実質組織部分には武田ら の報告と同様に腫瘍の填死および gliosisがみられ，NCS 投与の場合には組織学的に特に血管の变性が強いことが特 徵と思われた。一方，こうした組織学的变化は腄瘍腔內壁 より 5〜10 $\mathrm{mm}$ の深さでみられ, ACNUの場合より深達 度が少ない印象があり，NCSの活性值を含め深達度を明 確にする定量法がないため正確な histogram を求めにくい という難点はあるが，これはNCSとACNUの半減期あ るいは分子量の差によるものと考えられる。本治㞠法での

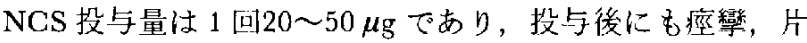

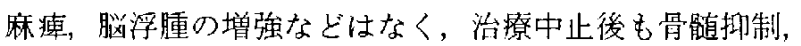
肺線維症, 肝機能障害, 腎機能障害などの副作用は起こら なかった。しかし，〈症例 6〉では 1 回投与量 $100 \mu \mathrm{g}$ で反 復したよころ，徐々に Ommaya's reservoirよりの穿刺滩 がキサントクロミーから血性となり，CTでも腫瘍内出血 が認められた。 以上より，NCSの投与量は 1 回 $50 \mu \mathrm{g}$ ま でが適当と思秃る。

今回はグリオーマに対する種々の治療後の維持療法とし て本療法を行ったが，局所療法を施行した主たる病变部の み治療効果が誌められていながら，蹃液腔内転移病巣の急 速な進行により死亡した〈症例 2〉のごよき例もあり，やは り脳腫瘍の維持療法としての局所療法の限界を示すもの上 言えよう。

\section{NCSのマクロファージ集皘作用}

腫瘍腔内 NCS 投与療法施行中は, 睡瘍腔内穿刺液の細
胞診を行って治㞠効果判定の目安とした。こうしたなか で，大型の phagocytosis を示才細胞の出現した症例があり， non-specific esterase 染色法などによりこの細胞はマクロフ アージであることが判明したため，NCS 療法とマクロフ アージの出現にはなんらかの関連性が示㖫された。沼崎 $ら^{8}$ 仕, sarcoma 180 細胞のマウス腹腔内移植実験で NCS 前投与の影響について娭討中，直接作用を発現しえない低 投与量の NCS がマウスに宿主介在性と考えられる腫塲抵 抗性を賦与するという事㬰を見い出し，さらにNCSがマ クロファージの活性化と細胞障害性リンパ球(cytotoxic lymphocytes)誘導の促進作用を持つことを報告している. また高橋11)も，低濃度の NCS が稩胞性鬼疫能(たとえば MLCなど)を賦活寸ることを指摘している，我々はNCS をモルモットの腹腔内に注人して滲出細胞を観察し，さら にBoyden chamber 法を用いてマクロファージの遊走活性 を測定した，その結果，NCSはin vivoではマクロファー ジ集積作用を持つが，in vitroでは值接の遊走活性は示さ ず，NCSのマクロファージ集積作用にはin vivoに打いて 関与寸る他の要因，すなわち同時に滲出する好中球やリン ハ球などの介在が必要であると考えられた5)。髄液腔内お よび腫疡腔内には多くの腫場細胞が浮遊しているが,こう した状態では実質性腫場の場合と異なり killer T cell の関 与よりをむしろ好中球やマクロファージなどの貪食細胞の 果す役割が大きく，睡瘍細胞の破壊に有効であると灾われ る.このような見地から，抗癌作用を持つNGSの腫痬腔 内投与療法は免疫療法としても有効な治療法と考えられ t.

\section{$\mathrm{V}$ まとめ}

1. 悪性グリオーマの寛解導入療法後の維持療法とし て, 残遺腫瘍腔内に䖪白性抗癌剂である neocarzinostatin （NCS）を反復投与した。腫湯腔が single cavity で腫瘍壁が 厚くない場合にはさわめて有効であったが，残遺腫演が大 きい場合には部分的に効果が得られた。

2. 本治療法においては抗癌剂の一般的副作用はなかっ たが，1回投与量が多かった症例で腫瘍內出血がみられ， 組織学的にも強い血管変性が認めら扎た。このことより， NCSの投与量は 1 回 $50 \mu \mathrm{g}$ までが適当と考えられた。

3. 本治療中, 腫瘍腔内にマクロファージが增加するこ とが判明したが，NCSにはこうした免投学的治療剂とし ての側面もみられ，腫瘍腔內投与には有効な薬剤であると 考えられた。

稿を終えるにあたり，NCS の基礎研究に関して御指導，御協 力を頂きました熊本大学微生物学教室 前田 浩 教授に深謝致し 
ます。

本論文の要旨は，第41回日本脸神経外科学会総全(1982年10月， 東京)において発表した。

\section{文献}

1) Heppner F: Local chemotherapy of brain tumors. Acta Neurochir (Wien) 11:287-293,1963

2）石田名香婎：ネオカルチノスタチンの作用機作。医のあゆ み 59:136-140,1966

3) Karnofsky DA, Burchenal JH: The clinical evaluation of chemotherapeutic agents in cancer, in Macleod (ed): Evaluation of Chemotherapeutic Agents. New York, Columbia University, 1949, pp 191-205

4) Kodama T, Matsukado Y, Uemura S: Intracapsular irradiation therapy of craniopharyngiomas with radioactive gold: Indication and follow-up results. Neurol Med Chir (Tokyo) 21: 49-58, 1981

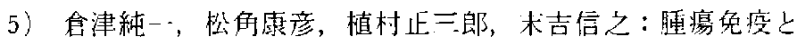
化学療法の相関 一Neocarzinostatin(NCS)のマクロファージ 集積作用について一. Neurol Med Chir (Tokyo) 23: 856-859, 1983

6）訟角康彦，前田 治，植村正三郎，倉津純一，園田 宽：

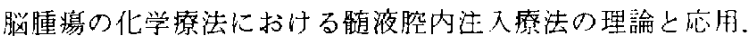
Pharmacokinetic one-compartment model とその臨床芯用第二 報 一Neocarzinostatin perfusionに上る臨床治娩一，癌と化㙩 9: $1933-1941,1982$

7) 松角康店，植村正三郎，会津純一：噵腔内脳腄瘍転移，脳 神外科 8: 1113-1123, 1980
8）沿崎洋三，岩野勝行，荻地幹雄，石用名香䧸：Neocarzinostatin (NCS)のマクロファージ活吽化作用. 医のあゆみ 123：992994,1982

9) Ringkjob R: Treatment of intracranial gliomas and metastasis carcinomas by local application of cytostatic agents. Acta Neurol Scand 44: 318-322, 1968

10）志村俊郎，中沢省三：悪性腫瘍に抢ける抗癌剂睡煌内局所 注入療法の踟床病理学的研究，这神外科 8: 35-42, 1980

11）高橋 誠：細胞性免疫能に及ぼすneocarzinostatin $\varrho$ 基礎 的，臨床的桱討，癌の臨 24:689-695, 1978

12）武田憲夫，出中隆一，鈴木康夫：悪性グリオーマにお付る $\mathrm{ACNU}$ 局所投与の有用性に関する恰討一病理組織学的所見 による一，第43回日本脳神経外科学会総会プログラム。千葉， $1984,261 \mathrm{pP}$

13）竹内一夫, 矢作保治, 上井 岝, 森本和大：脳灌流法に上

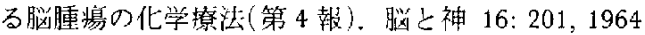

14) Tator $\mathrm{CH}$ : Intraneoplastic injection of CCNU for experimental brain tumor chemotherapy. Surg Neurol 7: 73-78, 1977

15）植村正三隗，松角康彦，園田寛，合津純；，大塚忠弘， 吉网進，吉田蝢正，河内正人，丸林 徹：Neocarzinostatin による悪性脳腫瘍の治療一内頸動脈動注および放射線照射併 用療法一. Neurol Med Chir (Tokyo) 26: 304-310, 1986

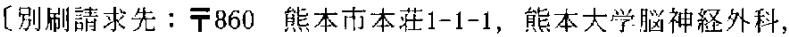
植村正三郎了 